\begin{tabular}{|c|c|}
\hline & $\begin{array}{l}\text { International Journal of Trend in Scientific } \\
\text { Research and Development (IJTSRD) }\end{array}$ \\
\hline 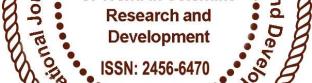 & International Open Access Journal \\
\hline 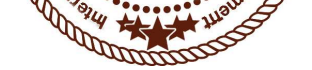 & ISSN No: 2456 - 6470 | www.ijtsrd.com | Volume - 2 | Issue - 2 \\
\hline
\end{tabular}

\title{
Current Scenario of Health Insurance in India: A Study Comprising Various Challenges and Measures for IT
}

\author{
Kunuma Das \\ Ph.D Scholar, Department of Economics, \\ Gauhati University, Guwahati, Assam, India
}

\section{ABSTRACT}

While considering the all-round development of a nation, health of its citizens is an inevitable part. But in many case it is seen that, especially in low income countries, people have to suffer a lot while accessing healthcare services. Out of pocket expenses for getting healthcare services make people vulnerable. In such a scenario, health insurance can be a very important mechanism for healthcare financing. Especially in a country like India where Government spends only $1.4 \%$ of GDP in healthcare, an efficient health insurance system is of dire necessity. In India, Health insurance is not as famous as life insurance. Although, health insurance penetration is growing but, still only less than one-fifth of India's population are covered with any kind of Insurance coverage. Health Insurance market faces many challenges including adverse selection, moral hazard, low awareness, lack of responsible authorities, etc. which really discourages the performance of health insurance in India. This paper mainly tries to give an overview of the health insurance system in India along with the problems and challenges faced by it.

Keywords: out of pocket expenses, Health Insurance, challenges, measures, overview, India

\section{INTRODUCTION}

Choices about financing healthcare services have become primary concern to health policy makers so as to achieve health policy goals. Dominance of out of pocket healthcare expenditure in most low income countries indicates that access to healthcare services is primarily a function of individual's ability to pay which can't be of equal in any case. Only $30 \%$ of total health expenditure is spent by Government of India is not at all sufficient to cover almost 1.21 billion populations. ${ }^{20}$ healthcare expenditure in India in 2014 constitutes almost $4.7 \%$ of GDP, but contribution of Government is only $1.4 \%$ of GDP. ${ }^{8}$ Majority (62.4\%) of total healthcare expenditure constitutes out-ofpocket payment at the time of service utilization. ${ }^{13}$ Based on 2015 estimates, only 288 million (28.8 crore) approximately, less than one-fifth of India's population, were covered by health insurance in India. ${ }^{10}$ In treating the in-patients, private institutions dominated both the rural $(58 \%)$ and urban areas $(68 \%)$ respectively. ${ }^{13}$ High value diagnostics and drugs make healthcare cost rapidly rising and in most of the cases it forces people to opt for borrowings, sale of physical assets in order to support their expenses on healthcare. Especially $24.9 \%$ of rural and $18.2 \%$ of urban households depend primarily on borrowings for meeting their healthcare expenditures. ${ }^{12}$ Many times ailments remained untreated due to financial constraints, the $52^{\text {nd }}$ report of NSS shows that $24 \%$ and $21 \%$ of untreated ailments in both rural and urban areas respectively was mainly due to lack of monetary resources. ${ }^{12}$ Again, among those who get hospitalized, approximately $25 \%$ are pushed below poverty line by catastrophic impact of out-of-pocket healthcare expenditure. ${ }^{16}$ Again, dual disease burden of communicable and Non-communicable diseases and coupled with spiraling health costs and poor healthcare delivery due to inadequate public spending on health along with lack of insurance coverage 
results in excessive financial burden on the poor and erosion in their incomes. ${ }^{2}$ In such a situation, health insurance can really work as a protective shield against any health related emergency. Purchase of health insurance not only brings peace of mind but also one can avail tax benefits under section $80 \mathrm{D}$ of the Income Tax Act, $1961 .^{2}$

In response to growing demand for health insurance, this paper tries to make an overview of Health Insurance business in India along with various challenges faced by it.

\section{THEORETICAL FRAMEWORK:}

\subsection{Health Insurance}

Health insurance is a kind of insurance coverage against uncertain health risks to an individual. It is a type of contract in between an insurer and an individual or group in which insurer agrees to provide specified health insurance cover at a particular "Premium". 3 Health insurer requires paying some or all of the healthcare costs in exchange for a premium. Either the insured pays costs out of pocket and is then reimbursed, or the insurer makes payments directly to the provider.

The rationale for Health Insurance is based on 'Laws of large numbers' which explains that the average behavior of a group of individuals is more predictable than that of a single individual. ${ }^{4}$ Thus, the rationale for pooling individual risks lies on the fact that the tendency to behave more systematically and predictably increases with the size of the group.

\subsection{Demands for Health Insurance:}

The conventional models of demand for health insurance assumes that under conditions of rationality and risk averseness, decisions to purchase insurance is based on the expected utility gain (Friedman and Savage, 1948; Arrow, 1963). ${ }^{6,1}$ According to this theory, the insurance is demanded because of the certainty it provides. Individual's perception towards the risk is also an important factor.

Again according to contingent theory, demand for health insurance is derived from the demand for an uncertain payoff in the ill state rather than demand for certainty or risk averseness (Zweiful and Breyer, 1997; Nyman, 1999a; Mas-Colell, Whinston, Green, 1995).). ${ }^{21,11,14,}$ Insurance is purchased when expected utility gain from the payoffs exceed the expected utility loss of the premium that could have been spent on other consumption.

Feldstein (1973), states that the price of healthcare or healthcare expenditure also has a relation with demand for insurance. Because, rising prices impose a risk to the net worth depletion during illness. ${ }^{7}$

Increased income and education also have link to the demand for insurance. Higher income decreases the opportunity cost associated with the purchase of health insurance (Van De Ven and Van Praag 1981). ${ }^{19}$ Mostly utility gains, expected from the insurance are derived from the expected medical need of the people which in turn is related with factors like age, job condition, pre-existing health status, marital status and so on (Barrett and Conlon 2003). ${ }^{3}$

Various socio-economic factors like- age, education, employment, gender and marital status etc have impact on demand for health insurance. Those employed and in better economic position are likely to purchase more health insurance (Butler 1999) ${ }^{5}$.

\subsection{Adverse Selection}

Presence of Adverse selection in health insurance market is really challenging (Van de Ven and Van Vlenit 1995). ${ }^{18}$ It is a situation where people having different health risks are not charged premium equal to their expected marginal cost of their insurance. In health insurance, the insurer is the uninformed party because he has no possibility to gather detailed information about the health status of his customers. While ignorant, the insurers have no other option than asking a premium based on an average expected health risk of the whole population. High risk people purchase the offered policy because the offered policy is advantageous concerning their health risks. However low risk people do not purchase this on average expected risk based insurance policy because the premium is too high with respect to their health risks. Consequently the customer base of the insurer consists mainly of high risk people.

\subsection{Moral Hazard}

This is the incentive to increase risky behavior because the adverse outcomes of that behavior are covered by insurance. Informational asymmetry is mentioned as the source of moral hazard. It is a tendency of the insured people to increase their consumption of healthcare. As much necessary care is unaffordable, demand for health insurance arises out of the desire to access certain services rather than risk aversion (Nyman 1999). ${ }^{14}$ 


\subsection{Forms of Health Insurance:}

Health Insurance is mainly categorized into four forms- Mandatory/social, voluntary, Employer provided and community based. Health insurance policies further classified as public and private. Public health insurance is insurance that is subsidized or paid for entirely by public (Government) funds. Conversely, Private health insurance is paid for in part or entirely by the individuals being covered. Two mandatory Government run health insurance schemes are- Employee State Insurance Scheme (ESIS) and Central Government Health Scheme (CGHS). For the sake of poor people Government of India launched some voluntary social health insurance schemes likeUniversal Health Insurance scheme in 2003 which was later transformed into Rastriya Swathya Bima Yojna on April1, 2008. Mediclaim, voluntary health insurance policy is offered by both Public and Private sector General Insurance companies. Again, Community health insurance schemes are there to serve the needs of the poor and are mainly offered by NGO's, Trusts and hospitals etc.

\section{OBJECTIVES:}

1. To provide an overview of health insurance in terms of its current performance, challenges faced by it.

Table 1: Health Insurance Premium over the last Five years (Rs.Crore)

\begin{tabular}{|l|l|l|l|l|l|}
\hline Sectors & $\mathbf{2 0 1 1 - 1 2}$ & $\mathbf{2 0 1 2 - 1 3}$ & $\mathbf{2 0 1 3 - 1 4}$ & $\mathbf{2 0 1 4 - 1 5}$ & $\mathbf{2 0 1 5 - 1 6}$ \\
\hline Public Sector General Insurers & 8015 & 9580 & 10841 & 12882 & 15591 \\
& $(61 \%)$ & $(62 \%)$ & $(62 \%)$ & $(64 \%)$ & $(64 \%)$ \\
\hline Private Sector General Insurers & 3445 & 4205 & 4482 & 4386 & 4911 \\
& $(27 \%)$ & $(27 \%)$ & $(26 \%)$ & $(22 \%)$ & $(20 \%)$ \\
\hline Stand Alone Health Insurers & 1609 & 1668 & 2172 & 2828 & 3946 \\
& $(12 \%)$ & $(11 \%)$ & $(12 \%)$ & $(14 \%)$ & $(16 \%)$ \\
\hline Industry Total & 13,069 & 15,453 & 17,495 & 20,096 & 24,448 \\
& & & & & \\
\hline
\end{tabular}

Source: Annual Report of IRDAI (2015-16).

Note: Figures in the bracket indicate the market-share in total HI premium.

From, the above Table 1, it is seen that the four public sector general insurance companies continued to contribute a major share at 64 percent of total health premium in 2015-16. Standalone health insurers have also contributed 16 percent of total health insurance premium in 2015-16, registering an increase of 2 percent over the previous year 2014-15. But, there is a drop in the share of private general insurers, whose share has come down from $22 \%$ in 2014-15 to $20 \%$ in 2015-16. The increasing share of both the Public sector General Insurers from $61 \%$ in $2011-12$ to $64 \%$ in 2015-16 and Standalone health insurers from 12\% in 2011-12 to $16 \%$ in 201516 respectively can be observed over the past five years because of the fact that Public sector companies might be offering the health insurance product at a subsidized price. But, Private health insurers remain an exception 
in this case only where the share has been in negative direction from $27 \%$ in $2011-12$ to $20 \%$ in $2015-16$. The health insurance industry in terms of total premium growth has been on a rapid progress and the reasons behind this can be termed as Medical inflation. The cost of medical treatment is growing 10-15\% year on year in India due to high costs on drugs and medical tests. ${ }^{20}$ Again, the private sector insurance companies have also raised the premium per insured to compensate for the high medical bills and also it is the effect of asymmetric information on the part of the insurer where the companies raise the price of the policies.

Table 2: Categorization of Health Insurance Premium (Rs. Crore)

\begin{tabular}{|l|l|l|l|l|l|}
\hline Class of Business & $\mathbf{2 0 1 1 - 1 2}$ & $\mathbf{2 0 1 2 - 1 3}$ & $\mathbf{2 0 1 3 - 1 4}$ & $\mathbf{2 0 1 4 - 1 5}$ & $\mathbf{2 0 1 5 - 1 6}$ \\
\hline $\begin{array}{l}\text { Government Sponsored } \\
\text { Schemes including RSBY }\end{array}$ & $\begin{array}{l}2225 \\
(17 \%)\end{array}$ & $\begin{array}{l}2348 \\
(15 \%)\end{array}$ & $\begin{array}{l}2082 \\
(12 \%)\end{array}$ & $\begin{array}{l}2474 \\
(12 \%)\end{array}$ & $\begin{array}{l}2425 \\
(10 \%)\end{array}$ \\
\hline $\begin{array}{l}\text { Group Business ( other than } \\
\text { Government business) }\end{array}$ & 6948 & 7186 & 8058 & 8899 & 11621 \\
\hline Individual Business & $(46 \%)$ & $(47 \%)$ & $(46 \%)$ & $(44 \%)$ & $(48 \%)$ \\
& 4896 & 5919 & 7355 & 8772 & 10353 \\
& $(37 \%)$ & $(38 \%)$ & $(42 \%)$ & $(44 \%)$ & $(42 \%)$ \\
\hline Grand Total & 13,069 & 15,453 & 17,495 & 20,096 & 24,448 \\
& & & & & \\
\hline
\end{tabular}

Source: Annual Report of IRDAI (2015-16).

Note: Figures in bracket indicate the share of each class of business in total health insurance premium

The above table 2 shows that it is the Group business that contributes the major share in health insurance premium among all over the five years, i.e- $48 \%$ in 2015-16. Individual Health Insurance business comes in the second place while calculating the market share in premium with $42 \%$ in the same year. Again, the Government sponsored health insurance business remains the lowest with $10 \%$ share in insurance premium. Most of the Government schemes do not require premium payment and again those which require is of very negligible. But, there has been a massive declining trend in Government health insurance premium contribution which is from $17 \%$ in 2011-12 to $10 \%$ in 2015-16. Due to fierce competition between the insurance companies, the premium for Government sponsored health insurance schemes keep falling since the last 4 or 5 years. Again, problems like information asymmetry and lack of awareness aggravates the matter.

Table3: Percentage distribution of person by coverage of health expenditure support

\begin{tabular}{|l|l|l|l|l|l|l|}
\hline & $\begin{array}{l}\text { Not } \\
\text { covered }\end{array}$ & $\begin{array}{l}\text { Government } \\
\text { funded } \\
\text { insurance } \\
\text { schemes }\end{array}$ & $\begin{array}{l}\text { empl. } \\
\text { (not Govt.) } \\
\text { supported } \\
\text { health } \\
\text { protection }\end{array}$ & $\begin{array}{l}\text { arranged } \\
\text { by household } \\
\text { with } \\
\text { insurance } \\
\text { company }\end{array}$ & Others & All \\
\hline Rural & 85.9 & 13.1 & 0.6 & 0.3 & 0.1 & 100 \\
\hline Urban & 82.0 & 12.0 & 2.4 & 3.5 & 0.2 & 100 \\
\hline
\end{tabular}

Source: NSSO $71^{\text {st }}$ roundreport

It is seen that, around $86 \%$ of rural households and $82 \%$ of urban households of India were still not covered under any scheme public or private, to support health expenditure. Lack of awareness, refusal of treatment by empanelled hospitals to BPL in many cases etc. are the main reasons behind poor coverage. Mostly in rural areas, the problem tends to be more prominent. 
However, Government was able to bring $13 \%$ and $12 \%$ of rural and urban population respectively under various Government funded insurance schemes like RSBY for unorganized and BPL people, ESI for organized and CGHS for central employees along with some state sponsored insurance schemes and role of Private medical health insurance still remains negligible. Private health insurance is basically characterized by high premium rates which hinder majority of the middle and low earning people to get enrolled.

\section{Table 4: Coverage of Persons under Health Insurance (Rs. Lakh)}

\begin{tabular}{|l|l|l|l|l|l|}
\hline Class of Business & 2011-12 & $\mathbf{2 0 1 2 - 1 3}$ & $\mathbf{2 0 1 3 - 1 4}$ & $\mathbf{2 0 1 4 - 1 5}$ & $\mathbf{2 0 1 5 - 1 6}$ \\
\hline $\begin{array}{l}\text { Government Sponsored } \\
\text { Schemes including RSBY }\end{array}$ & $\begin{array}{l}1612 \\
(76 \%)\end{array}$ & $\begin{array}{l}1494 \\
(72 \%)\end{array}$ & $\begin{array}{l}1553 \\
(72 \%)\end{array}$ & $\begin{array}{l}2143 \\
(74 \%)\end{array}$ & $\begin{array}{l}2733 \\
(76 \%)\end{array}$ \\
\hline $\begin{array}{l}\text { Group } \\
\text { (other than GOVT. Business) }\end{array}$ & 300 & 343 & 337 & 483 & 570 \\
\hline Individual Business & $(14 \%)$ & $(17 \%)$ & $(15 \%)$ & $(17 \%)$ & $(16 \%)$ \\
\hline Grand Total & $\begin{array}{l}206 \\
(10 \%)\end{array}$ & $(11 \%)$ & $(13 \%)$ & $\begin{array}{l}254 \\
(9 \%)\end{array}$ & $\begin{array}{l}287 \\
(8 \%)\end{array}$ \\
\hline
\end{tabular}

Source: Annual Report of IRDAI (2015-16).

Note: Figures in bracket indicate the share of each class of business in total number of persons covered

The Table shows that, the percentage of coverage of person under Government sponsored health insurance schemes is more than that of private insurance schemes. Again, the coverage under government schemes remain more or less stable but in case of individual business under private insurance have been declining i.e from $10 \%$ in $2011-12$ to $8 \%$ in $2015-16$. Adverse selection, moral hazard and lack of awareness are the major reasons for the private individual business still in the grim of poor scenario. Many people buy policies for tax saving but, which comprises only a small part of the population.

Table 5: Net Incurred Claims Ratio of Health Insurers (in percent)

\begin{tabular}{|l|l|l|l|l|l|}
\hline Class of business & $2011-12$ & $2012-13$ & $2013-14$ & $2014-15$ & $2015-16$ \\
\hline $\begin{array}{l}\text { Government sponsored } \\
\text { schemes including RSBY }\end{array}$ & $90 \%$ & $87 \%$ & $93 \%$ & $108 \%$ & $109 \%$ \\
\hline $\begin{array}{l}\text { Groups (other than Govt. } \\
\text { Business) }\end{array}$ & $100 \%$ & $104 \%$ & $110 \%$ & $116 \%$ & $120 \%$ \\
\hline Individual Business & $85 \%$ & $83 \%$ & $83 \%$ & $81 \%$ & 775 \\
\hline Grand total & $94 \%$ & $94 \%$ & $97 \%$ & $101 \%$ & $102 \%$ \\
\hline
\end{tabular}

Source: Annual Report of IRDAI (2015-16).

From the above table, it is observed that there has been an increase in the net ICR from 94\% in 2011-12 to $102 \%$ in $2015-16$. Again, the net ICR remain particularly high for Group business which is more than $100 \%$ over the years. High incurred claim ratios of most of the companies stand at more than 100\% which is not at all a good indication for insurance business. The main factor responsible for this is adverse selection or poor risk identification. Adverse selection is the result of asymmetric information which ends up with more risky portfolios of the insurance companies. It is also seen that, in most of the cases members converting outpatient procedures as inpatient, resulting in Healthcare spending of population with insurance is thrice that of the population without insurance. ${ }^{1}$

\subsection{Challenges:}

1. Lack of awareness: During 2015-16, the General and other health insurance companies have issued around 1.18 crore health insurance policies covering 35.90 crore persons, which is less than 
one-fifth of India's population and the underlying reason behind this poor coverage is due to lack of awareness or poor insurance literacy. ${ }^{8}$ A study made by Akila (2013) has found out that the dominant group of population $57 \%$ is unaware of health insurance. ${ }^{2}$

2. Lack of proper health infrastructure: lack of sufficient healthcare facilities often becomes a hurdle in health insurance coverage. The problem tends to become more serious in rural and distant places.

3. Lack of proper Regulation: absence of strict norms and responsible authorities lead to the problems of adverse selection and Moral Hazard in health insurance. Lack of efficient Third Party Administrator is also a growing concern.

4. Poverty: the capacity to pay premium is mostly absent among a sizeable number of population in India, which really pose a big difficulty in implementation of health insurance.

5. Lack of importance: health insurance has been not given due attention in front of lucrative tariff prices of other segments of insurance business.

6. Absence of product variety: it is seen that there is lack of product variety of health cover. It lacks the quality to meet the requirements of different segment of people including aged, youth, people with preexisting dieses etc.

Thus, development of insurance especially in the health segment requires a well-structured way to deal with all these challenges.

\section{SUGGESTIONS}

Rising premium resulting from High medical costs can be dealt with some measures like Hospital bills to be controlled through Health Management Organisation (HMO) and transparency to be initiated with the help of developed IT infrastructure which will help in increasing efficiency to reduce operating cost. Government must develop efficiency with respect to various publicly sponsored schemes so as to face the competition from the various new and innovative private individual and group insurance schemes. Again, in a country with large number of rural and poor population, lower insurance penetration in rural areas is really a matter of concern. Rural population face greater risk of being in unhealthy condition due to lower access to sanitation and pure drinking water and inside house pollution arising out of the smoke from coal or wood used as fuel. Moreover, they also face the financial hardship to cure any illness etc. Facilitating and enhancing Micro Insurance for the disadvantaged people in rural and backward areas is really important. Creating more awareness regarding health insurance and making all insurance providers proper responsible in delivering their services should be the prime focus of both the insurers and Government of the country. Poor insurance coverage, along with high incurred claim ratios in case of private players also marks a significant problem for the development of the insurance sector in India. So, to increase the health insurance penetration, Agents and private players must target new markets in rural and semi-urban areas. Moreover, Introduction of new product portfolios is also the need of the hour. TPAs in Insurance have to be more effective, so that the whole system of insurance can be made clear and efficient while dealing with the problem like information asymmetry.

Since, Insurance acts as a protection to high unexpected healthcare costs; it is the duty of all stakeholders to come forward and join hands to overcome all the challenges for the sake of survival of the industry. Finally, initiatives must be taken so as to facilitate Public-Private Partnership in a competitive environment.

\section{CONCLUSION}

In the backdrop of escalating population, the Health Insurance as a tool of advanced healthcare financing play an indispensible role. Although, India has the highest potential for Health Insurance, the penetration still remains lowest when compared to western economies. The growing health burden, and healthcare costs have accentuated the need of health insurance. Besides hospitalization coverage, many benefits in the form of cashless payment, tax benefits etc. can also be enjoyed from any kind of health insurance. In spite of this, we are unable to reap the benefits fully due to many issues like- the prevalence of high informal sector, adverse selection, moral hazard, lack of awareness and so on. The health insurance premium is in the increasing growth path which is mainly the result of high cost healthcare services. Poor coverage in health insurance mainly in rural areas shows the problem of lack of awareness regarding health insurance advantages. Again, high incurred claim ratios mainly in case of group business really hint to the matter of rising adverse selection and fraudulent cases in this industry. In such a situation Regulations and managed insurance market can play 
an effective role in moving health financing towards greater equity. Enhancement of Health Insurance industry with the help of Mass Marketing strategies like- Micro health insurance for the poor people, promotion of group insurance will be greatly helpful. All the stakeholders' like- healthcare providers, TPAs, Insurance agents, Insurance companies, Government and consumers must play a cohesive role towards increasing the health insurance penetration and density in India.

\section{REFERENCES}

1. Arrow,K.J. (1963). "Uncertainty and the Welfare Economics of Medical Care,"American Economic Review 53, pp: 941-973.

2. Akila, M (2013). "Penetration of Health Insurance sector in Indian market", IJM, Vol 3, No (1), pp:55-67

3. Barret, G.F. and Collon (2003). "Adverse Selection and the Decline in Private Health Insurance Coverage in Australia: 1989-95", Economic Record, 79(246).

4. Black, J. (1997). Oxford Dictionary of Economics. Oxford, OUP.

5. Butler, J. (1999) "Estimating Elasticities of Demand for Private Health Insurance in Australia", National Centre for Epidemiology and Population Health, Canberra.

6. Friedman, Milton and L. J. Savage (1948). "The Utility Analysis of Choices Involving Risk",Journal of Political Economy 56, pp:279304.

7. Feldstein., Martin S. (1973). "The Welfare Loss of Excess Health Insurance", Journal of Political Economy 81, pp: 251-280.

8. Insurance Regulatory Development Authority of India (2017): "Health Insurance in India- Issues and challenges," IRDAI JOURNAL, Vol 15, No (1), pp:6-62

9. Insurance Regulatory Development of India (2016). "Handbook on Health Insurance 2015-16" , Govt. Of India.

10. Insurance Regulatory Development Authority of India (2016). “ Annual Report 2015-16," Govt. Of India .

11. Mas, C., Andreu, Michael D., Whinston, Jerry R. Green. (1995). "Microeconomic TheOlY". New York: Oxford University Press.
12. Ministry of Statistics and Programme Implementation (1996). " Health In India: NSSO $52^{\text {nd }}$ Round, July 1995- june 1996," New Delhi.

13. Ministry of Statistics and Programme Implementation (2015): "Health In India: NSSO $71^{\text {st }}$ Round, January-June 2014," New Delhi.

14. Nyman, John A. (1999a). "The Value of Health Insurance: The Access Motive", Journal of Health Economics vol. 18(2), pp.:141-152.

15. Nagaraju, Y. (2014). "A study on Performance of Health Insurance schemes in India," IJIRP, Vol 2 (4): pp:9-19

16. Prinja, S., Kaur. M. and Kumar, R. (2012). "Universal Health Insurance in India: Ensuring equity, effeciency, and quality," IJCM, Vol 37(3), pp: 142-149

17. Rao, S (2004): "Health Insurance: Concepts, Issues and Challenges," EPW, Vol 39(34), pp:3835-3844

18. Van de Ven W. and Vlenit. (1995). "Consumer information surplus and adverse selection in Competitive health insurance markets: an empirical study", Journal of Health Economics 14.

19. Van De Ven, W.P.M.M. and B.M.S. Van Praag. (1981). "The Demand for Deductibles in Private Health Insurance", Journal of Econometrics, 17(2).

20. World Bank. (2017). "World health expenditure data(1995-2014)," Washington, D.C., United States

21. Zweifel, Peter and Friedrich,B. (1997). "Health Economics". New York: Oxford University Press. 